JURNAL NOMINAL / VOLUME VII NOMOR 2 / TAHUN 2018

\title{
PENGARUH PERSEPSI MAHASISWA AKUNTANSI MENGENAI KOMPENSASI REWARD DAN PUNISHMENT TERHADAP KECURANGAN PELAPORAN KEUANGAN DENGAN MOTIVASI KERJA SEBAGAI VARIABEL MODERASI
}

(Studi Eksperimen pada Mahasiswa Akuntansi Universitas Negeri Yogyakarta)

\section{THE EFFECT OF PERCEPTION OF ACCOUNTING STUDENT ABOUT REWARD, PUNISHMENT COMPENSATION TO FRAUDELENT FINANCIAL REPORTING WITH WORK MOTIVATION AS THE MODERATING VARIABLE (Experimental Study on Accounting Student of Yogyakarta State University)}

\author{
Elsya Prabowo \\ Program Studi Akuntansi Fakultas Ekonomi Universitas Negeri Yogyakarta \\ elsya.prabowo@gmail.com \\ Denies Priantinah \\ Staf pengajar ProgramStudi Akuntansi Universitas Negeri Yogyakarta \\ denies_priantinah@uny.ac.id
}

\begin{abstract}
Abstrak : Pengaruh Persepsi Mahasiswa Akuntansi Mengenai Kompensasi Reward dan Punishment Terhadap Kecurangan Pelaporan Keuangan Dengan Motivasi Kerja Sebagai Variabel Moderasi. Penelitian ini bertujuan untuk mengetahui: (1) Pengaruh Persepsi Mahasiswa Akuntansi mengenai Kompensasi Reward terhadap Kecurangan Pelaporan Keuangan. (2) Pengaruh Persepsi Mahasiswa Akuntansi mengenai Kompensasi Punishment terhadap Kecurangan Pelaporan Keuangan. (3) Motivasi Kerja Memoderasi Pengaruh Persepsi Mahasiswa Akuntansi mengenai Kompensasi Reward terhadap Kecurangan Pelaporan Keuangan. (4) Motivasi Kerja Memoderasi Pengaruh Persepsi Mahasiswa Akuntansi mengenai Kompensasi Punishment terhadap Kecurangan Pelaporan Keuangan. Teknik analisis data yang digunakan adalah one way analysis of variance dan analysis of covariance. Hasil penelitian menunjukkan (1) Terdapat pengaruh persepsi Mahasiswa Akuntansi mengenai Kompensasi Reward terhadap Kecurangan Pelaporan Keuangan. (2) Terdapat pengaruh persepsi Mahasiswa Akuntansi mengenai Kompensasi Punishment terhadap Kecurangan Pelaporan Keuangan. (3) Motivasi Kerja memperkuat pengaruh persepsi Mahasiswa Akuntansi mengenai KompensasiReward terhadap Kecurangan Pelaporan Keuangan. (4) Motivasi Kerja memperkuat pengaruh persepsi Mahasiswa Akuntansi mengenai Kompensasi Punishment terhadap Kecurangan Pelaporan Keuangan.
\end{abstract}

Kata kunci: Kompensasi, Reward, Punishment, Motivasi Kerja, Kecurangan Pelaporan Keuangan.

\begin{abstract}
The Effect Of Perception Of Accounting Student About Reward, Punishment Compensation To Fraudelent Financial Reporting With Work Motivation As The Moderating Variable. The aims of this research is to analize: (1) the effect of perception of accounting student about Reward Compensation to Fraudelent Financial Reporting. (2) the effect of perception of accounting student about Punishment Compensation to Fraudelent Financial Reporting. (3) Work Motivation moderating the effect of perception of accounting student about Reward Compensation to Fraudelent Financial Reporting. (4) Work Motivation moderating the effect of perception of accounting student about Punishment Compensation to Fraudelent Financial Reporting. Data analysis technique used a one way analysis of variance and analysis of covariance. The results of the research shows that: (1 there is an effect of perception of accounting student about Reward Compensation to Fraudelent Financial Reporting. (2) there is an effect of perception of accounting student about Punishment Compensation to Fraudelent Financial Reporting. (3) Work Motivation strengthens the effect of perception of accounting student about Reward Compensation to Fraudelent Financial Reporting. (4) Work Motivation strengthens the effect of perception of accounting student about Punishment Compensation to Fraudelent Financial Reporting.
\end{abstract}

Keywords: Compensation, Reward, Punishment, Work Motivation, Fraudelent Financial Reporting 


\section{JURNAL NOMINAL / VOLUME VII NOMOR 2 / TAHUN 2018}

\section{PENDAHULUAN}

Suatu perusahaan atau organisasi baik itu laba maupun nirlaba tentu memiliki tujuan yang ingin dicapai. Tujuan tersebut biasanya telah ditetapkan pada awal pendirian organisasi tersebut. Hal ini dikarenakan penetapan tujuan merupakan salah satu unsur pokok dalam suatu organisasi. Tujuan tersebut dapat tercapai apabila individu-individu dalam organisasi dapat bekerja sama dengan baik dalam mengelola sumber daya yang dimilikinya.

Sumber daya yang penting dalam suatu organisasi yaitu sumber daya manusia. Sumber daya manusia disini disebut dengan karyawan. Karyawan yang dimaksud yaitu karyawan dalam menentukan tercapainya tujuan. Diperlukannya strategi untuk mencapai suatu tujuan dalam organisasi, hal ini sangatlah tidak mudah. Masalah mendasar yang sering dihadapi dalam organisasi adalah bagaimana mengelola sumber daya manusia untuk melakukan tugas dengan sebaik-baiknya dalam rangka mencapai tujuan yang telah ditetapkan. Individuindividu dalam organisai juga diarahkan untuk menghindari kecurangan maupun tindakan tidak jujur dalam berkerja.

Kecurangan merupakan tindakan yang telah menarik perhatian di berbagai kalangan masyarakat. Kecurangan merupakan bentuk penipuan yang sengaja dilakukan sehingga dapat menimbulkan kerugian tanpa disadari oleh pihak yang dirugikan dan memberikan keuntungan bagi pelaku kecurangan. Menurut Moehirno, (2006: 67) bahwa terdapat hubungan yang erat antara penghargaan dan prestasi karyawan. Dalam upaya peningkatan karyawan usaha yang dilakukan organisasi tidak akan terlepas dari berbagai hal, diantaranya yaitu kompensasi yang diberikan kepada karyawan dan juga motivasi karyawan.

Tindakan individu yang baik sangat diperlukan dalam upaya menjaga kredibilitas organisasi tersebut. individu biasanya menginginkan kompensasi sebanyak mungkin sedangkan organisasi akan lebih memilih untuk mempertahankan gaji (Govindarajan, 2005:109). Selain kompensasi positif yaitu reward, individu juga dapat dipengaruhi oleh kompensasi negatif yaitu berupa punishment. Menurut Wibisono, (2015) Reward merupakan feedback positif yang diberikan oleh organisasi atas pencapaian yang telah dilakukan oleh individu. Sedangkan punishment merupakan suatu konsekuensi yang tidak menyenangkan atau tidak diinginkan yang diberikan oleh atasan atas suatu perilaku tertentu yang telah ditentukan (Ivancevich, et.al 2007).

Kejujuran merupakan dasar individu untuk melakukan kinerja guna mencapai suatu tujuan. Sehingga, perusahaan diharuskan mengelola sumber daya manusia dengan menggunakan strategi efektif. Strategi ini dirancang untuk 


\section{JURNAL NOMINAL / VOLUME VII NOMOR 2 / TAHUN 2018}

memotivasi para individu untuk berkerja sesuai dengan prosedur perusahaan supaya terhindar dari tindakan kecurangan. Beberapa organisasi telah membuat sistem kompensasi khusus untuk memotivasi individu dengan mengkombinasikan beberapa jenis kompensasi seperti reward dan punishment.

Association of Certified Fraud Examinations (ACFE) merupakan organisasi anti kecurangan terbesar di dunia dan sebagai penyedia utama pendidikan dan pelatihan anti kecurangan. Menurut ACFE atau Association of Certified Fraud Examinations (2012) terdapat 1.388 kasus kecurangan di seluruh dunia. Kasus kecurangan ini juga semakin bertambah setiap tahun. Menurut data ACFE jumlah persentase kecurangan pelaporan keuangan yang terjadi pada tahun 2010 adalah $86,3 \%$ sedangkan pada tahun 2012 jumlah presentase penyalahgunaan aset meningkat menjadi 86,7\%.Jenis kecurangan lain yang juga mengalami peningkatan adalah kasus korupsi dan kecurangan laporan keuangan. Menurut ACFE atau Association of Certified Fraud Examinations (2012), pada tahun 2010 jumlah persentase kasus korupsi yang terjadi adalah $32,8 \%$ dan pada tahun 2012 jumlah persentase kasus korupsi meningkat menjadi $33,4 \%$. Untuk kasus kecurangan laporan keuangan yang terjadi pada tahun 2010 adalah jumlah 4,8\% dan pada tahun 2012 meningkat menjadi 7,6\%. Dari data tersebut dapat dilihat bahwa jumlah kasus fraud yang mengalami peningkatan paling tinggi adalah kasus kecurangan laporan keuangan.

Kecurangan laporan keuangan di Indonesia banyak juga terjadi dalam level perusahaan, baik perusahaan swasta maupun pemerintah. Pada 6 Desember 2012, diumumkan skor Indonesia dalam Corruption Perception Index (CPI) adalah 32 dan menempati urutan ke 118 dari 176 negara yang diukur tingkat korupsinya (Transparancy International, 2012). Hal ini dapat dilihat dari banyaknya kasus-kasus yang terkait dengan isu korupsi dan praktek kecurangan seperti likuidasi beberapa bank, diajukannya manajemen BUMN maupun swasta ke pengadilan, kasus kejahatan perbankan, manipulasi pajak, dan lain-lain (Wilopo, 2006). Dari data-data tersebut dapat dilihat bahwa jumlah kasus fraud yang mengalami peningkatan paling tinggi adalah kasus kecurangan pelaporan keuangan.

Selain jenis kecurangan pelaporan keuangan memiliki peningkatan yang paling besar, disisi lain jumlah kasus kecurangan yang paling tinggi adalah penyalahgunaan aset oleh karyawan. Data dari ACFE tersebut juga sesuai dengan penelitian sebelumnya yang dilakukan oleh KPMG's. Menurut KPMG's Barometer Fraud Survey 2013 hasil survey dari tahun 2010 sampai dengan 2012 dikatakan bahwa employee fraud yang dilakukan oleh karyawan adalah tipe kecurangan yang 


\section{JURNAL NOMINAL / VOLUME VII NOMOR 2 / TAHUN 2018}

paling banyak terjadi. Kecurangan yang dilakukan oleh karyawan ini bisa dilakukan oleh karyawan itu sendiri atau berkelompok. Dengan adanya data ini diperlukan tindakan yang dilakukan perusahaan atau sebuah instansi untuk mengurangi adanya tindakan kecurangan. Hal ini dikarenakan kecurangan yang ada di lingkungan kerja akan merugikan banyak pihak seperti rekan kerja dan perusahaan itu sendiri.KPMG's. Menurut KPMG's Barometer Fraud Survey 2013 hasil survey dari tahun 2010 sampai dengan 2012 dikatakan bahwa employee fraud yang dilakukan oleh karyawan adalah tipe kecurangan yang paling banyak terjadi. Kecurangan yang dilakukan oleh karyawan ini bisa dilakukan oleh karyawan itu sendiri atau berkelompok. Dengan adanya data ini diperlukan tindakan yang dilakukan perusahaan atau sebuah instansi untuk mengurangi adanya tindakan kecurangan. Hal ini dikarenakan kecurangan yang ada di lingkungan kerja akan merugikan banyak pihak seperti rekan kerja dan perusahaan itu sendiri.

Sistem pengendalian manajemen yang tepat diperlukan untuk menghindari yang menyimpang. Selain itu, motivasi kerja juga sangat membantu dalam pembentukan sistem kompensasi bagi individu.

Penelitian yang dilakukan oleh Sung dan Choi (2009) menggunakan motivasi kerja sebagai variabel mederasi pada maupun mengurangi tindakan kecurangan pelaporan yang dilakukan karyawan. Manajemen atas akan lebih memperhatikan sistem tersebut guna mengurangi tidakan kecurangan yang beredar. Ada beberapa cara yang dapat digunakan oleh instansi atau perusahaan untuk mengurangi terjadinya hal tersebut yaitu diantaranya dengan cara penerapan reward dan punishment yang tepat.

Menurut Raja Ali, dkk (2011) semakin sering karyawan memperoleh penghargaan atas tindakan baik yang dilakukan, semakin besar pula karyawan akan mengulangi tindakan yang baik. Sebaliknya, semakin sering individu mendapatkan sanksi atau hukuman atas kesalahan yang dilakukan maka akan semakin berkurang pula tindakankesalahan yang dilakukan. Dengan kata lain keberhasilan organisasi ditentukan olehbaiknya pemberian penghargaan dan adilnya pemberian hukuman. Selain itu, reward dan punishment merupakan suatu cara yang dapat diberlakukan oleh organisasi agar individu dapat memperbaiki sikap dan perilakunya

hubungan antara lima faktor utama personalitas dan kinerja kreatifitas. Secara keseluruhan data yang didapat dari penelitian ini menunjukkan bahwa motivasi secara signfikan memoderasi hubungan antara kompensasi dan kecurangan akuntansi serta kinerja kreatifitas. 


\section{JURNAL NOMINAL / VOLUME VII NOMOR 2 / TAHUN 2018}

Berdasarkan uraian latar belakang permasalahan di atas terkait kompensasi reward, punishment, kecurangan pelaporan keuangan, dan motivasi kerja. Peneliti ini mengambil judul "Pengaruh Persepsi Mahasiswa Akuntansi mengenai Kompensasi Reward dan Punishment terhadap Kecurangan Pelaporan Keuangan dengan Motivasi Kerja sebagai Variabel Moderasi.

\section{METODE PENELITIAN}

\section{Jenis Penelitian}

Penelitian ini menggunakan jenis penelitian eksperimen adalah penelitian yang berusaha memanipulasi satu atau lebih variabel kausal kemudian mengukur efek manipulasi tersebut terhadap satu atau lebih variabel dependen (Sunyoto, 2013).

\section{Waktu dan Tempat Penelitian}

Penelitian ini dilakukan di Universitas Negeri Yogyakarta dengan respondennya adalah mahasiswa akuntansi angkatan 2015. Waktu pelaksanaannya adalah bulan Maret sampai dengan Mei 2018.

\section{Subjek Penelitian}

Penelitian ini mengambil populasi mahasiswa akuntansi Universitas Negeri Yogyakarta angkatan 2015. Penelitian ini bersifat populatif dimana semua anggota populasi dalam penelitian digunakan sebagai responden sehingga tidak dilakukan teknik pengambilan sampel.
Prosedur

Teknik pengumpulan data dalam penelitian ini adalah dengan menggunakan metode kasus dan kuesioner.Dalam penelitian ini, parisipan akan mengumpulkan data menggunakan kasus dan kuesioner. Kasus ini akan digunakan untuk mengukur variabel kompensasi Reward, Punishment, dan Kecurangan Pelaporan Keuangan. Sementara itu, kuesioner ini akan digunakan untuk mengukur variabel motivasi kerja.

Sebelum dilakukan uji hipotesis, penelitian ini mendistribusikan 66 kasus dan kuesioner terlebih dahulu ke mahasiswa akuntansi angkatan 2016 untuk dilakukan uji validitas dan reliabiltas. Sehingga penelitian ini menggunakan uji coba tidak terpakai. Lalu untuk tahap kedua peneliti mendistribusikan 69 kasus dan kuesioner ke mahasiswa akuntansi angkatan 2015.

\section{Data, Intrumen, dan Teknik Pengumpulan}

Untuk uji hipotesis menggunakan yaitu 1) One Way Analysis of Variance digunakan untuk menguji hipotesis pertama dan kedua. Untuk mencari pengaruh persepsi mahasiswa akuntansi mengenai kompensasi reward terhadap kecurangan pelaporan keuangan dan pengaruh persepsi mahasiswa akuntansi mengenai kompensasi punishment terhadap kecurangan pelaporan keuangan. 2) Analysis of Covariance dilakukan untuk menguji hipotesis ketiga dan keempat. Untuk mencari apakah 


\section{JURNAL NOMINAL / VOLUME VII NOMOR 2 / TAHUN 2018}

motivasi kerja memoderasi pengaruh persepsi mahasiswa akuntansi mengenai kompensasi reward terhadap kecurangan pelaporan keuangan dan apakah motivasi kerja memoderasi pengaruh persepsi mahasiswa akuntansi mengenai kompensasi punishment terhadap kecurangan pelaporan keuangan.

HASIL PENELITIAN DAN PEMBAHASAN

\section{Hasil Penelitian}

Analisis deskripsi data yang disajikan dalam penelitian ini meliputi Minimum, Maksimum, Standar Deviasi (SD), dan Mean

Tabel 1. Hasil Analisis Deskriptif

\begin{tabular}{|c|c|c|c|c|c|}
\hline Jenis Kompensasi & $\mathbf{N}$ & & Max & M & $\mathbf{S}$ \\
\hline Reward & 1 & & 3 & 0,624 & 1,529 \\
\hline Punishment & 1 & & 3 & 0,791 & 2,000 \\
\hline Rewarl\&Punishment & 1 & & 3 & 0,752 & 1,765 \\
\hline Netral & 1 & & 6 & 0,686 & 4,667 \\
\hline ot & 6 & 1 & 6 & 1,471 & 2, \\
\hline
\end{tabular}

Sumber: Data Primer yang Diolah

Berdasarkan pada tabel 14 diatas, dapat diketahui bahwa nilai minimum data kecurangan pelaporan keuangan adalah 1 sedangkan nilai maksimumnya adalah 6 . Rata-rata variabel kecurangan pelaporan keuangan dalam penelitian ini berkisar antara 1,529 sampai dengan 4,667. Dengan artian semakin kecil nilai rata-rata maka akan semakin baik karena semakin kecil nilainya maka partisipan akan memilih untuk melakukan penolakan dan pelaporan kecurangan dengan tingkatan tinggi. Sebaliknya, semakin tinggi rata-rata maka semakin buruk karena semakin besar nilainya maka partisipan akan memilih untuk menerima dan tidak melaporkan kecurangan dengan tingkatan tinggi.

Berikut adalah hasil uji hipotesis: 1) one way analysis of variance ini digunakan untuk menguji apakah ada perbedaan nilai rata-rata (mean) yang signifikan diantara kelompok-kelompok yang lebih dari 2 grup tentang suatu hal. Analisis ini digunakan untuk hipotesis pertama dan hipotesis kedua.

Tabel 2. Analisis Regresi H1 dan H2

\begin{tabular}{|c|c|c|c|}
\hline Variabel & $\mathbf{F}$ & Signifikansi & Keterangan \\
\hline Reward & 23,655 & $\begin{array}{lllll}0 & 0 & 0 & 0\end{array}$ & H1 diterima \\
\hline Punishment & 35,814 & $\begin{array}{lllll}0 & 0 & 0 & 0 & 0\end{array}$ & $\mathrm{H} 2$ diterima \\
\hline
\end{tabular}

Sumber : Data Primer yang Diolah

H1 : Persepsi Mahasiswa Akuntansi mengenai Kompensasi Reward berpengaruh terhadap Kecurangan Pelaporan Keuangan.

Hipotesis pertama $\left(\mathrm{H}_{1}\right)$ akan diterima jika $F_{\text {hitung }} \geq F_{\text {tabel }}$ atau $P_{\text {valuekurang }}$ dari 0,05 $(<0,05)$, sedangkan hipotesis akan ditolak jika $\mathrm{F}_{\text {hitung }} \leq \mathrm{F}_{\text {tabel }}$ atau $\mathrm{P}_{\text {value }}$ lebih dari 0,05 (>0,05). Hasil pengujian $\mathrm{H}_{1}$ menunjukkan bahwa nilai $F_{\text {hitung }}$ sebesar 23,655 lebih besar dari $F_{\text {tabel }}$ yaitu 3,92. Informasi berikutnya diperoleh dari nilai $\mathrm{P}_{\text {value }}$ Signifikan sebesar 0,000 lebih kecil dari 0,05. Dengan demikian hipotesis pertama $\left(\mathrm{H}_{1}\right)$ diterima yaitu Persepsi Mahasiswa Akuntansi mengenai 


\section{JURNAL NOMINAL / VOLUME VII NOMOR 2 / TAHUN 2018}

Kompensasi Reward akan berpengaruh terhadap Kecurangan Pelaporan Keuangan. Maka dapat disimpulkan bahwa dengan adanya perlakuan kompensasi reward yang diterapkan seperti pemberian bonus dan peningkatan jabatan, maka menurut persepsi Mahasiswa Akuntansi UNY akan lebih memerangi tindakan kecurangan pelaporan keuangan baik menghindari tindakan penyalahgunaan ataupun memanipulasi data dalam pembuatan laporan keuangan, selain itu Mahasiswa Akuntansi UNY akan lebih termotivasi dalam bekerja sesuai dengan aturan..

H2 : Persepsi Mahasiswa Akuntansi mengenai Kompensasi Punishment berpengaruh positif terhadap

\section{Kecurangan Pelaporan Keuangan.}

Hipotesis kedua $\left(\mathrm{H}_{2}\right)$ akan diterima jika $F_{\text {hitung }} \geq F_{\text {tabel }}$ atau $P_{\text {valuekurang dari } 0,05}$ $(<0,05)$, sedangkan hipotesis akan ditolak jika $F_{\text {hitung }} \leq \mathrm{F}_{\text {tabel }}$ atau $\mathrm{P}_{\text {value }}$ lebih dari 0,05 $(>0,05)$. Hasil pengujian $\mathrm{H}_{2}$ menunjukkan bahwa nilai $F_{\text {hitung }}$ sebesar 35,814 lebih besar dari $F_{\text {tabel }}$ yaitu 3,92. Informasi berikutnya diperoleh dari nilai

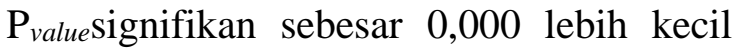
dari 0,05. Dengan demikian hipotesis kedua $\left(\mathrm{H}_{2}\right)$ diterima yaitu Persepsi Mahasiswa Akuntansi mengenai Kompensasi Punishment akan berpengaruh terhadap Kecurangan Pelaporan Keuangan. Maka dapat disimpulkan bahwa dengan adanya perlakuan kompensasi punishment yang diterapkan seperti teguran, surat peringatan, skorsing, dan pemecatan, maka menurut persepsi Mahasiswa Akuntansi UNY akan lebih memerangi tindakan kecurangan pelaporan keuangan baik menghindari tindakan penyalahgunaan ataupun memanipulasi data dalam pembuatan laporan keuangan, selain itu Mahasiswa Akuntansi UNY akan lebih termotivasi dalam bekerja sesuai dengan aturan.

analysis of covariance ini digunakan untuk mengetahui atau untuk melihat pengaruh perlakuan terhadap peubah respon dengan mengontrol peubah lain yang kuantitatif. Analisis ini digunakan untuk hipotesis ketiga dan hipotesis keempat.

Tabel 2. Analisis Regresi H1 dan H2

\begin{tabular}{|c|c|c|c|}
\hline Variabel & $\mathbf{F}$ & Signifikansi & Keterangan \\
\hline Reward "Ilotitasi Kerja & 23,196 & 0,0000 & H3 diterima \\
\hline 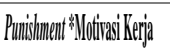 & 35,169 & 0,0000 & H4 diterima \\
\hline
\end{tabular}

Sumber : Data Primer yang Diolah

H3 : Motivasi Kerja memoderasi pengaruh Persepsi Mahasiswa Akuntansi mengenai Kompensasi Reward terhadap Kecurangan Pelaporan Keuangan.

Hipotesis ketiga $\left(\mathrm{H}_{3}\right)$ akan diterima jika $F_{\text {hitung }} \geq F_{\text {tabel }}$ atau $P_{\text {value }}$ kurang dari 0,05 $(<0,05)$, sedangkan hipotesis akan ditolak jika $F_{\text {hitung }} \leq \mathrm{F}_{\text {tabel }}$ atau $\mathrm{P}_{\text {value }}$ lebih dari 0,05 $(>0,05)$. Hasil pengujian $\mathrm{H}_{3}$ menunjukkan bahwa nilai $F_{\text {hitung }}$ sebesar 23,196 lebih besar dari $F_{\text {tabel }}$ yaitu 3,07. Informasi berikutnya diperoleh dari nilai $\mathrm{P}_{\text {value }}$ signifikan sebesar 0,000 lebih kecil dari 0,05. Dengan demikian hipotesis ketiga 


\section{JURNAL NOMINAL / VOLUME VII NOMOR 2 / TAHUN 2018}

$\left(\mathrm{H}_{3}\right)$ diterima yaitu Motivasi Kerja akan memoderasi pengaruh Persepsi Mahasiswa Akuntansi mengenai Kompensasi Reward terhadap Kecurangan Pelaporan Keuangan. Maka dapat disimpulkan bahwa motivasi yang dimiliki oleh Mahasiswa Akuntansi UNY akan memperkuat pengaruh persepsi mahasiswa akuntansi mengenai kompensasi reward yang diterapkan dan akan memerangi tindakan kecurangan pelaporan keuangan baik menghindari tindakan penyalahgunaan ataupun memanipulasi data dalam pembuatan laporan keuangan.

\section{H4 : Motivasi Kerja memoderasi} pengaruh Persepsi Mahasiswa Akuntansi mengenai Kompensasi Punishment terhadap Kecurangan Pelaporan Keuangan.

Hipotesis keempat $\left(\mathrm{H}_{4}\right)$ akan diterima jika $F_{\text {hitung }} \geq F_{\text {tabel }}$ atau $P_{\text {value }}$ kurang dari 0,05 $(<0,05)$, sedangkan hipotesis akan ditolak jika $F_{\text {hitung }} \leq \mathrm{F}_{\text {tabel }}$ atau $\mathrm{P}_{\text {valuel }}$ lebih dari 0,05 (>0,05). Hasil pengujian $\mathrm{H}_{4}$ menunjukkan bahwa nilai $F_{\text {hitung }}$ sebesar 35,169 lebih besar dari $F_{\text {tabel }}$ yaitu 3,07. Informasi berikutnya diperoleh dari nilai

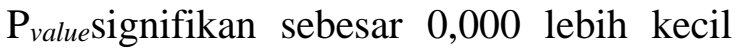
dari 0,05. Dengan demikian hipotesis keempat $\left(\mathrm{H}_{4}\right)$ diterima yaitu Motivasi Kerja akan memoderasi pengaruh Persepsi Mahasiswa Akuntansi mengenai Kompensasi Punishment terhadap Kecurangan Pelaporan Keuangan. Maka dapat disimpulkan bahwa motivasi yang dimiliki oleh Mahasiswa Akuntansi UNY akan memperkuat pengaruh persepsi mahasiswa akuntansi mengenai kompensasi punishment yang diterapkan dan akan memerangi tindakan kecurangan pelaporan keuangan baik menghindari tindakan penyalahgunaan ataupun memanipulasi data dalam pembuatan laporan keuangan.

\section{Interpretasi Hasil}

a) Pengaruh Persepsi Mahasiswa Akuntansi mengenai Kompensasi Reward terhadap Kecurangan

\section{Pelaporan Keuangan}

Hasil pengujian yang dilakukan menunjukkan bahwa $\mathrm{H}_{1}$ diterima karena persepsi mahasiswa akuntansi mengenai kompensasi reward berpengaruh terhadap kecurangan pelaporan keuangan. Nilai signifikansi pada hasil pengujian adalah 0,000 . Nilai signifikansi pada hipotesis ini kurang dari 0,05. Nilai $F_{\text {hitung }}$ adalah 23,655 lebih besar dari $F_{\text {tabel }}$ yakni 3,92. Mean pelaporan keuangan pada kompensasi reward ini adalah 1,765 meanini berada di bawah perlakuan netral yakni 3,257. R squared pada hipotesis ini yakni 0,261 yang artinya besar pengaruh kompensasi reward terhadap pelaporan keuangan sebesar 26,1\%. Maka dapat disimpulkan bahwa dengan adanya perlakuan kompensasi reward yang diterapkan seperti pemberian bonus dan peningkatan jabatan, maka menurut persepsi Mahasiswa Akuntansi UNY akan lebih memerangi tindakan kecurangan pelaporan keuangan baik menghindari tindakan penyalahgunaan 


\section{JURNAL NOMINAL / VOLUME VII NOMOR 2 / TAHUN 2018}

ataupun memanipulasi data dalam pembuatan laporan keuangan, selain itu Mahasiswa Akuntansi UNY akan lebih termotivasi dalam bekerja sesuai dengan aturan.

Hasil penelitian ini mendukung penelitian yang dilakukan oleh Caesar Marga Putri (2012) yang menunjukkan bahwa jalur pelaporan non-anonymous pada rewardmodel akan lebih efektif dalam melaporkan company'swrongdoing dibanding structuralmodel. Selain itu, hasil penelitian dari Pradipha Wisnu Wibisono (2015) yang menyatakan bahwa dengan mendapatkan hadiah atau ditetapkannya reward, maka karyawan cenderung akan mendukung kebijakan perusahaan dalam memerangi Fraud. Disisi lain, penelitian Nur Ratri K \& Wahyu Meiranto (2012) mengatakan bahwa kesesuaian kompensasi tidak dapat mengurangi kecenderungan kecurangan akuntansi, karena keinginan untuk memperoleh peningkatan bonus dan jabatan yang lebih tinggi membuat manajemen berani mengkondisikan kecenderungan kecurangan akuntansi di perusahaan dengan menggambarkan laba perusahaan yang terus meningkat.

b) Pengaruh Persepsi Mahasiswa Akuntansi mengenai Kompensasi Punishment terhadap Kecurangan Pelaporan Keuangan

Hasil pengujian yang dilakukan menunjukkan bahwa $\mathrm{H}_{2}$ diterima karena persepsi mahasiswa akuntansi mengenai kompensasi punishment berpengaruh terhadap kecurangan pelaporan keuangan. Nilai signifikansi pada hasil pengujian adalah 0,000. Nilai signifikansi pada hipotesis ini kurang dari 0,05 . Nilai $F_{\text {hitung }}$ adalah 35,814 lebih besar dari $F_{\text {tabel }}$ yakni 3,92. Mean pelaporan keuangan pada kompensasi punishment ini adalah 1,647 mean ini berada di bawah perlakuan netral yakni 3,371. R squared pada hipotesis ini yakni 0,348 yang artinya besar pengaruh kompensasi punishment terhadap pelaporan keuangan sebesar 34,8\%. Maka dapat disimpulkan bahwa dengan adanya perlakuan kompensasi punishment yang diterapkan seperti teguran, surat peringatan, skorsing, dan pemecatan, maka menurut persepsi Mahasiswa Akuntansi UNY akan lebih memerangi tindakan kecurangan pelaporan keuangan baik menghindari tindakan penyalahgunaan ataupun memanipulasi data dalam pembuatan laporan keuangan, selain itu Mahasiswa Akuntansi UNY akan lebih termotivasi dalam bekerja sesuai dengan aturan.

Hasil penelitian ini mendukung penelitian yang dilakukan oleh R.Lynn Hanan (2004) yang menyatakan bahwa kompensasi punishment berpengaruh terhadap pelaporan keuangan karena semakin besar punishment seperti teguran, surat peringatan, maupun skorsing maka karyawan akan menghindari kecurangan pada pelaporan keuangan. Karyawan akan termotivasi untuk bekerja dengan baik dan 


\section{JURNAL NOMINAL / VOLUME VII NOMOR 2 / TAHUN 2018}

menghindari kecurangan atau kesalahan dalam bekerja. Murphy \& Dacin (2011) mengatakan bahwa dengan meningkatkan punishment terhadap sebuah kejahatan, maka dapat membuat pelakunya menjadi takut untuk melakukan kejahatan yang sama untuk kedua kalinya. Penelitian Murphy dan Dacin juga mengatakan bahwa pelaku Fraud akan mempertimbangkan konsekuensi tindakannya, apabila konsekuensi yang diberikan lebih besar dari keuntungan yang diterima ketika melakukan Fraud maka akan memutuskan untuk tidak melakukan Fraud. Disisi lain, penelitian Nur Ratri K \& Wahyu Meiranto (2012) mengatakan bahwa kesesuaian kompensasi tidak dapat mengurangi kecenderungan kecurangan akuntansi, karena keinginan untuk memperoleh peningkatan bonus dan jabatan yang lebih tinggi membuat manajemen berani mengkondisikan kecenderungan kecurangan akuntansi di perusahaan dengan menggambarkan laba perusahaan yang terus meningkat.

\section{c) Motivasi Kerja memoderasi pengaruh persepsi Mahasiswa Akuntansi mengenai Kompensasi Reward terhadap Kecurangan Pelaporan Keuangan}

Hasil pengujian yang dilakukan menunjukkan bahwa $\mathrm{H}_{3}$ diterima karena motivasi kerja memoderasi pengaruh persepsi mahasiswa akuntansi mengenai kompensasi reward terhadap kecurangan pelaporan keuangan. Nilai signifikansi pada hasil pengujian adalah 0,000 . Nilai signifikansi pada hipotesis ini kurang dari 0,05. Nilai $F_{\text {hitung adalah 23,196 lebih besar }}$ dari $\mathrm{F}_{\text {tabel }}$ yakni 3,07. Hasil penelitian ini menunjukkan bahwa motivasi dapat memperkuat pengaruh persepsi mahasiswa akuntansi mengenai kompensasi reward seperti pemberian bonus atau penghargaan oleh atasan kepada bawahan terhadap kecurangan pelaporan keuangan. Maka dapat disimpulkan bahwa motivasi yang dimiliki oleh Mahasiswa Akuntansi UNY akan memperkuat pengaruh persepsi mahasiswa akuntansi mengenai kompensasi reward yang diterapkan dan akan memerangi tindakan kecurangan pelaporan keuangan baik menghindari tindakan penyalahgunaan ataupun memanipulasi data dalam pembuatan laporan keuangan.

Hasil penelitian ini mendukung penelitian yang dilakukan oleh Herpen dan Praag (2004) tentang pengaruh kompensasi dan kondisi kerja terhadap kinerja karyawan dengan motivasi sebagai variabel moderasi yang menyatakan bahwa motivasi memperkuat pengaruh kompensasi terhadap kinerja karyawan. Disisi lain, penelitian oleh Eko Muryanto (2014) menyatakan bahwa motivasi tidak mempengaruhi hubungan antara kompensasi dan kinerja pegawai. Selain itu, motivasi kerja tidak bertindak sebagai variabel moderasi dalam hubungan antara kompensasi dan kinerja pegawai. 


\section{JURNAL NOMINAL / VOLUME VII NOMOR 2 / TAHUN 2018}

\section{d) Motivasi Kerja memoderasi pengaruh persepsi Mahasiswa \\ Akuntansi Kompensasi Punishment terhadap Kecurangan Pelaporan Keuangan}

Hasil pengujian yang dilakukan menunjukkan bahwa $\mathrm{H}_{4}$ diterima karena motivasi kerja memoderasi pengaruh persepsi mahasiswa akuntansi mengenai kompensasi punishment terhadap kecurangan pelaporan keuangan. Nilai signifikansi pada hasil pengujian adalah 0,000. Nilai signifikansi pada hipotesis ini kurang dari 0,05. Nilai $F_{\text {hitung }}$ adalah 35,169 lebih besar dari $F_{\text {tabel }}$ yakni 3,07. Hasil penelitian ini menunjukkan bahwa motivasi dapat memperkuat pengaruh persepsi mahasiswa akuntansi mengenai kompensasi punishment seperti pemberian bonus atau penghargaan oleh atasan kepada bawahan terhadap kecurangan pelaporan keuangan. Maka dapat disimpulkan bahwa motivasi yang dimiliki oleh Mahasiswa Akuntansi UNY akan memperkuat pengaruh persepsi mahasiswa akuntansi mengenai kompensasi punishment yang diterapkan dan akan memerangi tindakan kecurangan pelaporan keuangan baik menghindari tindakan penyalahgunaan ataupun memanipulasi data dalam pembuatan laporan keuangan.

Hasil penelitian ini mendukung penelitian yang dilakukan oleh Herpen dan Praag (2004) tentang pengaruh kompensasi dan kondisi kerja terhadap kinerja karyawan dengan motivasi sebagai variabel moderasi yang menyatakan bahwa motivasi memperkuat pengaruh kompensasi terhadap kinerja karyawan. Disisi lain, penelitian oleh Eko Muryanto (2014) menyatakan bahwa motivasi tidak mempengaruhi hubungan antara kompensasi dan kinerja pegawai. Selain itu, motivasi kerja tidak bertindak sebagai variabel moderasi dalam hubungan antara kompensasi dan kinerja pegawai.

\section{PENUTUP}

\section{Simpulan}

Persepsi Mahasiswa Akuntansi mengenai Kompensasi Reward akan berpengaruh terhadap Kecurangan Pelaporan Keuangan.Persepsi Mahasiswa Akuntansi mengenai Kompensasi Punishment akan berpengaruh terhadap Kecurangan Pelaporan Keuangan.Motivasi Kerja akan memoderasi pengaruh persepsi Mahasiswa Akuntansi mengenai Kompensasi Reward terhadap Kecurangan Pelaporan Keuangan. Motivasi Kerja akan memoderasi pengaruh persepsi Mahasiswa Akuntansi mengenai Kompensasi Punishment terhadap Kecurangan Pelaporan Keuangan.

\section{Saran}

Berdasarkan hasil penelitian tersebut, untuk mahasiswa diharapkan dalam menghadapi adanya kecurangan perlu disikapi lebih baik untuk menghadapi ketika berada pada lingkungan kerja nanti. Ketika menjadi seorang karyawan di 


\section{JURNAL NOMINAL / VOLUME VII NOMOR 2 / TAHUN 2018}

perusahaan dan memiliki atasan, karyawan harus memerangi segala bentuk kecurangan pada perusahaan.

Untuk instansi diharapkan dapat memberikan kompensasi berupa reward dan punishment perlu diterapkan guna memberikan semangat dan motivasi bagi karyawan supaya bekerja sesuai dengan harapan dan aturan instansi. Motivasi kerja karyawan perlu dijaga dengan baik oleh atasan supaya karyawan bekerja dengan baik dan menghindari tindakan tidak jujur dalam bekerja.

Untuk penelitian selanjutnya diharapkan dapat menggunakan subyek penelitian yang sudah bekerja sebagai akuntan di perusahaan sehingga hasil dari penelitian nanti lebih dapat dipertanggungjawabkan. Peneliti selanjutnya sebaiknya memberikan pilihan jenis kompensasi yang lebih banyak dan tidak hanya Reward dan Punisment saja agar pilihan kompensasi dari partisipan terwakili sesuai dengan harapannya. Penelitian selanjutnya diharapkan untuk memastikan tempat, suasana dan waktu pelaksanaan eksperimen dalam sebuah kondisi yang benar-benar kondusif sehingga akan tercipta sebuah penghayatan terhadap treatment yang diberikan sebagai sebuah syarat yang dihasilkannya data eksperimen yang berkualitas. Penelitian selanjutnya dapat menggunakan pretestdalam menentukan partisipan kedalam berbagai kelompok kasus yang ada

\section{DAFTAR PUSTAKA}

ACFE. (2012). Report To The Nation On Occupational Fraud And Abuse.

Anthony dan Govindarajan. (2005). Management Control System. Edisi Pertama. Jakarta: Salemba Empat.

Caesar Marga Putri. (2012). Pengujian Keefektifan Model Whistleblowing: Pendekatan Eksperimen. Tesis: Universitas Gajah Mada.

Eko Muryanto. (2011). Pengaruh Kompensasi terhadap Kinerja dengan Motivasi Kerja sebagai Variabel Moderating. Skripsi: Universitas Sebelas Maret.

Ivancevich, Konopaske Dan Matteson. (2007). Perilaku Manajemen Dan Organisasi: alih bahasa Gina Gania. Jakarta : Erlangga.

Hannan, R. L., V. B. Hoffman dan D. V. Mosser. (2004). Bonus versus Penalty: Does Contract Frame Affect Employee Effort?.Experimental Business Research 2: Hlm. 151-169.

Herpen, Marco Van dan Marco Van Praag. (2004). Wage Structure and The Incentive Effect of Promotions. Tinbergen Institute Discussion Paper Vol.3 No.20; April 2004.

KPMG. (2013). fraud, Bribery and Corruption Survey 2012. KPMG International Cooperative, New Zwaland.

Moeheriono. (2006). PengukuranKinerja BerbasisKompetensi. Jakarta: Raja Grafindo Persada.

Murphy, Pamela R \& M Tina Dacin. (2011) Psychologi Pathways to Fraud: Understanding and Preventing Fraud. Journal of Business Ethics, Vol 101. Pp 601-618. 
Nur Ratri \& Wahyu Meiranto. (2012). Analisis Faktor-Faktor yang berpengaruh terhadap Kecenderungan Akuntansi dengan Perilaku Tidak Etis sebagai Variabel Intervening. Skripsi: Universitas Diponegoro.

Raja Ali, dkk. (2011). Analisis Reward dan Punishment pada Kantor Perum Damri Makasar. Skripsi: UNHAS.

Sung and Choi. (2009). Do Big Five Personality Factors Affect Individual Creativity? The Moderating Role of Extrinsic Motivations. Journal of Social Behavior and Personality 20:Hlm. 143-156.

Sunyoto, D. (2013). MetodePenelitianAkuntansi. Bandung: PT. Refika Aditama.

Transparency International, (2012). CorruptionPerceptionsIndex Result.

Wibisono, P.W. (2015). Pengaruh Reward and Punishment dan Job Rotation terhadap Fraud. Skripsi: Fakultas Ekonomi Universitas Negeri Yogyakarta.

Wilopo. (2006). Analisis Faktor-Faktor Yang Berpengaruh Terhadap Kecenderungan Kecurangan Akuntansi: Studi Pada Perusahaan Publik Dan Badan Usaha Milik Negara di Indonesia. Jurnal Riset Akuntansi Indonesia. Vol. 9 No.3 : 346-366. 